Article

\title{
Ecomuseums in China: Challenges and Defects to the Existing Practical Framework
}

\author{
Meng $\mathrm{Li}^{*}(\mathbb{D})$ and Gehan Selim $(\mathbb{0}$
}

check for

updates

Citation: Li, M.; Selim, G.

Ecomuseums in China: Challenges and Defects to the Existing Practical Framework. Heritage 2021, 4, 1868-1882. https://doi.org/10.3390/ heritage 4030105

Academic Editor: Robin Skeates

Received: 15 July 2021

Accepted: 14 August 2021

Published: 17 August 2021

Publisher's Note: MDPI stays neutral with regard to jurisdictional claims in published maps and institutional affiliations.

Copyright: (c) 2021 by the authors. Licensee MDPI, Basel, Switzerland. This article is an open access article distributed under the terms and conditions of the Creative Commons Attribution (CC BY) license (https:// creativecommons.org/licenses/by/ $4.0 /)$.
Architecture \& Urbanism Research Group, School of Civil Engineering, University of Leeds, Woodhouse Lane, Leeds LS2 9JT, West Yorkshire, UK; g.selim@leeds.ac.uk

* Correspondence: cnml@leeds.ac.uk

\begin{abstract}
This paper examines the shortcomings of the existing practical framework of ecomuseums in China. The social context of China's ecomuseum practice is critically analysed and elaborated to show the particularity of community and community participation in the Chinese context. In this context, the framework of Chinese ecomuseum practice is critically examined to illustrate the defects. This study is based on a literature analysis; the existing Chinese and English literature on the theory and practice of ecomuseums in China has been critically reviewed and analysed. The study found that the existing framework lacks people-oriented long-term development goals and a precise definition of roles of all parties, which has resulted in a dilemma for relationship of ecomuseums and communities in the country. Based on existing studies on ecomuseums in China and other areas, the study also offers corresponding suggestions to modify the existing framework.
\end{abstract}

Keywords: heritage conservation; community participation; sustainable development; Chinese cultural context

\section{Introduction}

Ecomuseums around the world provide an increasing number of different themes and models to protect both cultural and natural heritage owing to their flexible framework. Although there is no universal approach, ecomuseum ultimately have a huge and profound impact on history, culture, environment, heritage, tourism, and long-term community sustainability [1]. Some ecomuseums aim to preserve cultural resources such as traditions and identity [2] (p. 54); some aim to preserve the lifestyle of countryside, handicrafts [3] and natural resources [4]. There are also open-air ecomuseums that attempt to preserve industrial archaeology, traditional rural areas, evolution of urbanisation and memories [3]. An ecomuseum is different from a traditional museum, as shown below $[5,6]$ :

- $\quad$ Traditional Museum = building + collections + expert staff + public visitors;

- $\quad$ Ecomuseum $=$ territory + heritage + memory + population.

Rather than being housed in one or more buildings, an ecomuseum is rooted in tangible and intangible, natural and cultural resources within a geographic territory. Its practice preserves and displays memory and identity in community's daily life to make the place special. The community must be engaged in establishing and maintaining the ecomuseum in order to preserve their memory, to recreate and pass on their identity to the future, and to achieve sustainable development of the community. As defined by Davis [7] (p. 199), an ecomuseum is 'a community-based museum or heritage project that supports sustainable development'. Community willingness and recognition are the most important cornerstone of community participation in ecomuseum practice. Every community is unique; therefore, the willingness and needs of different communities depend on the definition of their members [8]. The willingness and awareness of the community should be reflected not only at the decision-making stage but also throughout construction and setting of ecomuseums' goals [9]. In the practice of ecomuseum, indepth communication with the relevant community is vital, where all changes happen 
slowly through constant communication [10]. An in-depth understanding of local culture and heritage by communities and other relevant parties is also fundamental for effective participation; therefore, constant internal and external education must have a place in the practice [11,12]. An ecomuseum is more like a long-term educational and sustainable means of local and social development. By participating in ecomuseums, people gain knowledge and education, learn about themselves and others, and work together to solve problems in local and social sustainability [13]. For instance, ecomuseum can significantly improve the social environment, economy, vitality, justice and public welfare in rural areas [14].

There are many great examples of the practice in the world to uncover the outstanding community participation in ecomuseums, such as the District Six Museum in Cape Town, South Africa [15,16], the Ak-Chin Him Dak Ecomuseum in Arizona [17-19], the Retracing Salford Project in Salford, UK [20] and the ongoing Discovering Southwell Project in Southwell, UK [21]. Although these outstanding practices have occurred in different eras, social backgrounds and countries, their practical processes can be abstracted into a similar framework. This practical framework often has a tough start, initiated by a small number of community residents with the help of external scholars. The initial practice may be nonprofessional, but it is important that the community does not abandon the long-term self-nurturing, in order to root the ecomuseum in the community. The AK-Chin Him Dak Ecomuseum, for example, radically enabled the community that was in an economic and cultural dilemma to walk on the road towards independence and confidence [19]. Back in the 1980s, the culture of Ak-chin Indian community in Arizona was significantly threatened by the science technology development and outside culture; under the influence of a national Indian unification movement, the community began to consider preserving its own culture. With the help of external professionals, the community council decided to embark on the journey of building an ecomuseum. In 1987, the ecomuseum board set ambitious two-year goals: to create communities that understand the function and role of museums and archives; cultivate community internal management ability; and design appropriate cultural facilities. The community ultimately completed the process of self-discovery and nurturing through visiting cultural institutions such as archives, museums, historical sites and regular formal and informal community information dissemination activities. Constant self-nurturing led them to establish a long-term community development goal of lifelong learning, which then initiated effective cooperation with a local university. The university agreed to create a degree program in museum and archive management for the community, which attracted more and more young people in the community to be enrolled in the program, and then return to the community after graduation and continue to serve the ecomuseum. In 1990, as a result of the community's efforts, authority of the ecomuseum was completely passed from external consultants to the community, who is the owner and manager of the ecomuseum. After a long process of consultation and self-nurturing, the ecomuseum's central building was opened in 1991. Four years of community involvement with external assistant was how the process of the ecomuseum took root. The opening of the new building was a milestone, suggesting a sustainable long-term development plan for the community to be formed, which was also a harbinger of a better future.

However, the practice of ecomuseums in China presents a completely different characteristic. In contrast to the practice framework that has a difficult start, Chinese ecomuseums tend to have a relatively easy start but then lack sustainability. Therefore, the research question of this paper is: what are the defects in the existing practical framework of ecomuseums in China, and how could the defects in this framework be improved? This paper offers an in-depth critical analysis of the social context in China and the challenges existing in the practice of Chinese ecomuseums in the last 30 years, thus illustrating the shortcomings in the existing practical framework in the country. This study is an extension of and supplement to previous studies criticising Chinese ecomuseum practices. It not only explains the root of the challenges but, more importantly, points out the specific problems in the practical framework, and provides recommendations for overcoming these challenges. 


\section{Secondary Literature as the Research Method}

Secondary data analysis means to analyse the existing data collected by others [22], which is also an empirical research method, which follows the same research principles and steps as the analysis of original data [23]. Analysis of secondary literature helps to validate research questions and hypotheses repeatedly. It is undeniable that before most research topics are investigated, there have been many existing relevant secondary literature and data, which more or less involve research questions and hypotheses [22,24]. Based on the question about the defects in the practical framework of China's ecomuseums, this study has examined the existing research on ecomuseums in China, which includes both the literature in Chinese and English. Community participation in the practices of ecomuseums in China is the focus of this paper; hence, when selecting the literature, ecomuseum, China, and community are the three keywords. This study is the basis of a relatively long-term research, i.e., a doctoral project, and we have had relatively plenty of time to understand the practice and development of ecomuseums in China. The entire reviewing process has taken more than one year (from 2019 to 2020) and is still ongoing. In the preliminary reviewing, because we wanted to obtain a wider range of research perspectives and views, we chose a relatively large and less bounded database. The authors searched the English literature through Google Scholar, and the Chinese literature was searched through the CNKI (Chinese National Knowledge Infrastructure). The retrieval results are massive, and the English research literature on ecomuseums in China is mainly concentrated among several scholars, e.g., William Nitzky [25-28], Katharina Massing [29,30] and Nunzia Borrelli [31], and an amount of literature also needs to be screened. For instance, a search for ecomuseum on CNKI has more than 2,000 results, and a search for ecomuseum plus community obtains nearly 200 studies. After extensive searching, the evaluation and screening process is particularly important. On the one hand, it can help the authors avoid spending too much time on secondary data that does not meet the requirements of relevance and quality; on the other hand, it can help to further clarify the research problems. The evaluations of secondary data and original data are similar, which is essentially the evaluation of their reliability and validity. Secondary data already exist and can be evaluated before being. The approaches of evaluation are to examine the presentation of data sources, collectors and research objectives in the existing literature [32]. For example, the screening of journal sources can avoid the use of some substandard secondary sources. An important screening criterion is the journal level of publication; CSSCI (Chinese Social Sciences Citation Index) source journals were used as the screening criteria; after the second screening, the number of Chinese literature on ecomuseums was about 200, and the number of studies on the performance of communities in ecomuseums was 20. Moreover, the evaluation of the authors of secondary sources is equally important. This study pays great attention to and draws plenty of inspiration from the conclusions drawn from the fieldwork and practical experience, for example, studies by Lili Fang (e.g., [33-35]) and Shouyong Pan (e.g., [36-43]), who are important representatives of the theory and practice of ecomuseums in China. Finally, an objectivity rarely interfered with by other purposes of existing studies is also one of the important screening indicators. Representative Chinese and English doctoral theses were also considered, e.g., by Kai Yin [44], William Nitzky [25] and Katharina Massing [30], as they provided a wider and more diverse perspective of research. The 'Papers of International Ecomuseum Form, Guizhou, China 2005' was studied in-depth, not only because it is known as the 'bible' of Chinese ecomuseum studies but also because it contains many experiences from other parts of the world. The comparison and analysis of the above research literature provide evidence for the viewpoints put forward in this study, and practices from other regions in the world provide a reference for the conclusions of this study.

The major benefit of secondary data analysis is that it provides a way to obtain relatively accurate research positioning at the lowest cost [45]. However, this does not mean that the use of secondary data as the main research method can be separated from the systematic analysis process. As mentioned, secondary data also need to be treated like 
primary data, retrieved and encoded using data analysis methods, and ultimately woven into topics at all levels that respond to the research question. After retrieving the secondary data, the reflexive thematic analysis (reflexive TA) was adopted as the main approach to data analysis. The reflexive TA was proposed by Virginia Braun and Victoria Clarke in 2006, which is used to identify, analyse and report underlying themes in data [46]. Reflexive TA emphasises a full qualitative research philosophy, emphasising the deep interaction between researchers and data as well as the influence of different context; hence, the codes and themes proposed by it have strong fluidity. Themes emerge as researchers dig deeper into the data, rather than looking for evidence in the data based on a given theme or structure [47]. In line with this philosophy, we were fully familiar with the secondary data involved and coded the opinions, conclusions, and segments of collecting data; thus, different themes emerged, to explain, in the social and cultural context of China, the special interaction among heritage management and community participation ecomuseum practice. These particularities reveal the challenges and defects of the existing ecomuseum framework in China. In addition, the existing studies on practice of ecomuseums outside China are coded and analysed in the same way. Through the primary themes formed by each code, we can see that even in a completely different social context, some approaches can still be woven into the practice of ecomuseum in China, thus improving the existing practical framework. This also provides a basis for our discussions and suggestions.

\section{Ecomuseums and Community Participation in China}

Ecomuseum practices in China is a top-down process led by the government from the very beginning, which differs fundamentally from other parts of the world. The idea of the "ecomuseum" was first introduced in China in 1986. It has been claimed that by 2008, 16 ecomuseums had been established in China [48], and this had increased to 30 by 2014 [49]. However, this is not accurate, for there are no official statistics about the number of ecomuseums in China, and in some cases, similar projects to ecomuseums were named differently [30]. At present, there are at least three generations of ecomuseums in China, as identified by Donghai Su, the founder of ecomuseums in China [42]. The first generation was an international collaboration project between the Chinese and Norwegian government which focused on the culture and territory of ethnic minority groups that were often located in backward and isolated villages far from cities in southwest China, e.g., Suojia Ecomuseum. Compared with the first generation, the second generation of ecomuseums are more professional and sustainable [50], e.g., the " $1+10$ " Ecomuseums Project in Guangxi Province. The third generation became more diversified: ecomuseums emerged not only in remote villages, but also in urban areas [30], e.g., the Anji Ecomuseum in Zhejiang Province and the "Sanfang Qixiang" Community Museum in Fujian Province. Moreover, the content of the third generation of ecomuseums also broadened, focussing not only on folk and traditions but also on regional industries [48].

After nearly 30 years of development, the practice of ecomuseums in China is still questioned by many, especially in regard to its relationship with the community, and the effective and sustainable conservation of local culture and heritage through this relationship. First of all, the ecomuseums cannot protect cultural heritage effectively, which, when combined with tourism, aggravates the loss of local culture [51,52]. The reason is that the existing ecomuseums in China cannot balance the relationship between heritage protection and the pursuit of economic interests by local communities and governments. Furthermore, a number of scholars have specifically discussed the significance of community participation for the long-term development of ecomuseums, e.g., [31,53,54], but under the top-down administrative framework of the state, ecomuseums in China cannot achieve effective community participation at all $[51,55]$. Moreover, Su [56] proposed that communities have to go through 'cultural consignment' to 'cultural autonomy' in order to become owners of their culture; meanwhile, the community has to experience three stages (the interest-driven stage, the emotion-driven stage and the knowledge-driven stage) to achieve cultural autonomy. The phenomenon of 'cultural consignment' is as follows: the 
discovery, explanation and development of a regional culture is not in the hands of local communities but in those of others. This has led to the loss and variation of the pioneering and revolutionary nature of ecomuseums in China [44]. These questions are fundamentally related to the meaning of community and community participation in the Chinese context.

The term 'community' is referred to as shequ in China. Originally, 'community' is a concept closely related to psychology and sociology. Gusfield [57] explained two implications of 'community': groups concentrated in the same geographic territory or groups connected beyond regional limits, by specific human relationships. McMillan and Chavis [58] (p. 9) proposed that the term 'community' had four elements: membership, influence, integration and fulfilment of needs, and shared emotional connection. In the context of China, the term 'community' has a political meaning and represents the downward extension of the state's administrative function. It is not a bottom-up product, but the terminal administrative departments set up by the state, playing a connective role of reporting to higher levels and making known to lower levels [59] (p. 154).

On the one hand, members of a community are often citizens operating within an administrative area, rather than groups automatically connected by a particular emotion or relationship. The administrative colour endows the community with greater management function, which can be more direct and effective in dealing with collective emergencies. For instance, during the COVID-19 pandemic, community organisations around the country made a great contribution to the effective nationwide lockdown and to living services to residents during the lockdown, as well as nucleic acid detection and personnel flow monitoring after the lockdown lifted, following the unified management and command of the state. On the other hand, this kind of government-led community cannot really achieve effective community participation. Even though community performs many functions to serve the people who live there, it still represents the interests of the public sector, rather than the will of the grassroots [60]. Most of the time, community is relatively indifferent to the requirements of residents and does not consider the problem comprehensively from the residents' perspectives [59].

In the countryside, the term community has not so far been widely used. When describing community participation in rural China, it is more intuitive to use the term 'villager participation', because community is often divided by village boundaries. Village is the basic unit of village community governance, and the Communist Party of China (CPC) still enjoys supreme leadership in the grassroots society [61]. Rural community is under management of a CPC branch committee in each village (cunzhibu) and the villagers' self-governance committee (cunweihui). Community organizations have administrative functions which must give priority to the public interest and must be under the leadership of the CPC.

Therefore, community participation in China is not a pure bottom-up movement, such that its universality, effectiveness and depth are often questioned. One example is community participation in heritage conservation, which is the focus of this paper. As Den [62] (p. 272) argued, 'heritage was more helpfully seen not as an absolute idea, but rather a relative concept which depends on the cultural consensus of the particular group of people who cherish it'. This means that heritage-related communities should be given more power to determine, interpret, narrate and construct their own heritage. Nevertheless, overall community participation in heritage conservation in China is not satisfactory. J. $\mathrm{Li}$ et al. [63] assessed community participation in management and conservation process of 36 World Heritage Sites in China that have been inscribed for the World Cultural Heritage List by the assessment framework they developed. According to their assessment, cultural heritage management in China is definitely a government-led process with limited community involvement. 'Most properties have insufficient involvement of residents in decision-making, and the focus of management is placed more on the presentation of heritage materiality than the improvement of community traditional life' [63] (p. 9). This relates to the top-down operation of Chinese society as a whole; hence, we can also see that China has a complex top-down administrative system to manage heritage. 
J. Lu [64] explained that in addition to the State Administration of Cultural Heritage $(\mathrm{SACH})$, many central departments are involved in the management of cultural heritage, such as the Ministry of Construction, the State Ethnic Affairs Commission, the State Administration for Religious Affairs, the Ministry of Civil Affairs, the Chinese Academy of Sciences, the Ministry of Land and Resources and the State Environmental Protection Administration. The efforts of the SACH in setting up a national conservation framework and coordinating resources across the country are visible [63], but on the other hand, it shows that administrative power extends to the very end and does not leave much room for community participation and decision making.

On the one hand, J. Li et al.'s [63] assessment also suggests that in the absence of participation generally, some World Cultural Heritage sites, which are closely related to human activities, have achieved good community participation, even participation in decision-making processes, such as heritage landscapes related to traditional agricultural production or inhabited ancient villages. In contrast, the lowest levels of community participation tended to be in sites that were far from daily lives, such as grottoes. However, effectively connecting community activities and heritage is a huge challenge. Head [65] has made a powerful argument regarding the community participation challenges faced in China today:

First, governments tend to retain control of these processes through funding, service contracts and regulation. Government institutions find it difficult to devolve power and control. Second, the capacity and motivation of citizens to participate effectively, or to create alternative forums, remains a weakness in community engagement strategies [65] (p. 452).

In short, community participation in heritage conservation faces two challenges: government empowerment and community preparation. In this regard, any community or organization (e.g., NGOs, [60] p. 653) needs to be empowered by the state in order to achieve its legitimacy. Furthermore, communities also need to be well prepared in regard to knowledge and capabilities. One crucial issue among many problems facing China's historical conservation efforts is 'the absence of knowledge among ordinary Chinese of their long and complex history' [66] (p. 2). This lack of public awareness and ability to preserve heritage is more prominent in rural areas. Heritage considered precious by cultural departments is often dismissed by villagers as worthless; as for the rich traditional customs, handicrafts and other kinds of ICH, villagers also think it is not elegant [67]. Moreover, villagers' awareness, motivations and initiatives to participate in conservation are related to living standards. Until the community achieves a satisfactory standard of living, it is harsh to ask them to actively preserve heritage without considering daily lives. Hence, it is now common in China for villagers to engage in commercial development of ancient villages in order to obtain more tourism revenue to improve their living conditions, and the local area eventually loses its soul owing to lack of protection (for example the Lijiang ancient town mentioned in [68] p. 93).

Consequently, establishing a mechanism for community participation in heritage protection in China should not only awaken the community's awareness of heritage but also consider the sustainable development of the community associated with the heritage. In other words, it is necessary to make the community understand the short-term, mediumterm and long-term benefits that participation in heritage protection can bring them. However, this is still a challenge, as it requires long-term and sustainable partnerships between the community and various stakeholders: 'Despite several community-based organisations being set up, in general, residents still lack resources to negotiate with different stakeholders and challenge any government decisions deviating from their interests' [63] (p. 9).

\section{Challenges the Ecomuseum Framework Facing in China}

Similar to other heritage conservation activities in China, the most serious challenge that ecomuseums are facing is community participation. On the one hand, ecomuseum 
practice has been applied within a top-down administrative framework of national operation. This macro national framework is unbreakable; hence, the ecomuseum has a utopian nature in China [69]. The pioneering and revolutionary nature of the ecomuseum in the context of China have been discarded and transformed into a socialist ideology [44]. In the existing practical framework (Figure 1), local government is in a leading role and external professionals dominate design and planning, and communities are passively led to participate. The former two authorities represent top-down administrative power and the academic authority of social elites, while the role of the community and other NGOs in the practice is relatively weak. In other words, the practice is led by a few elites from the decision-making stage; this is not much different from other heritage activities. For instance, owing to the macro administrative framework, neither the management nor the staff of Suojia Ecomuseum in the first-generation ecomuseums are local villagers; rather, they are all cadres sent by the cultural departments [52]. In the second-generation projects, the local government and outside experts still play the leading roles, and it is still difficult for the local community to hold the right to cultural interpretation [70]. Although the third generation aims to increase community participation, Su's response in a 2011 interview still reflected the government's unquestionable dominance:

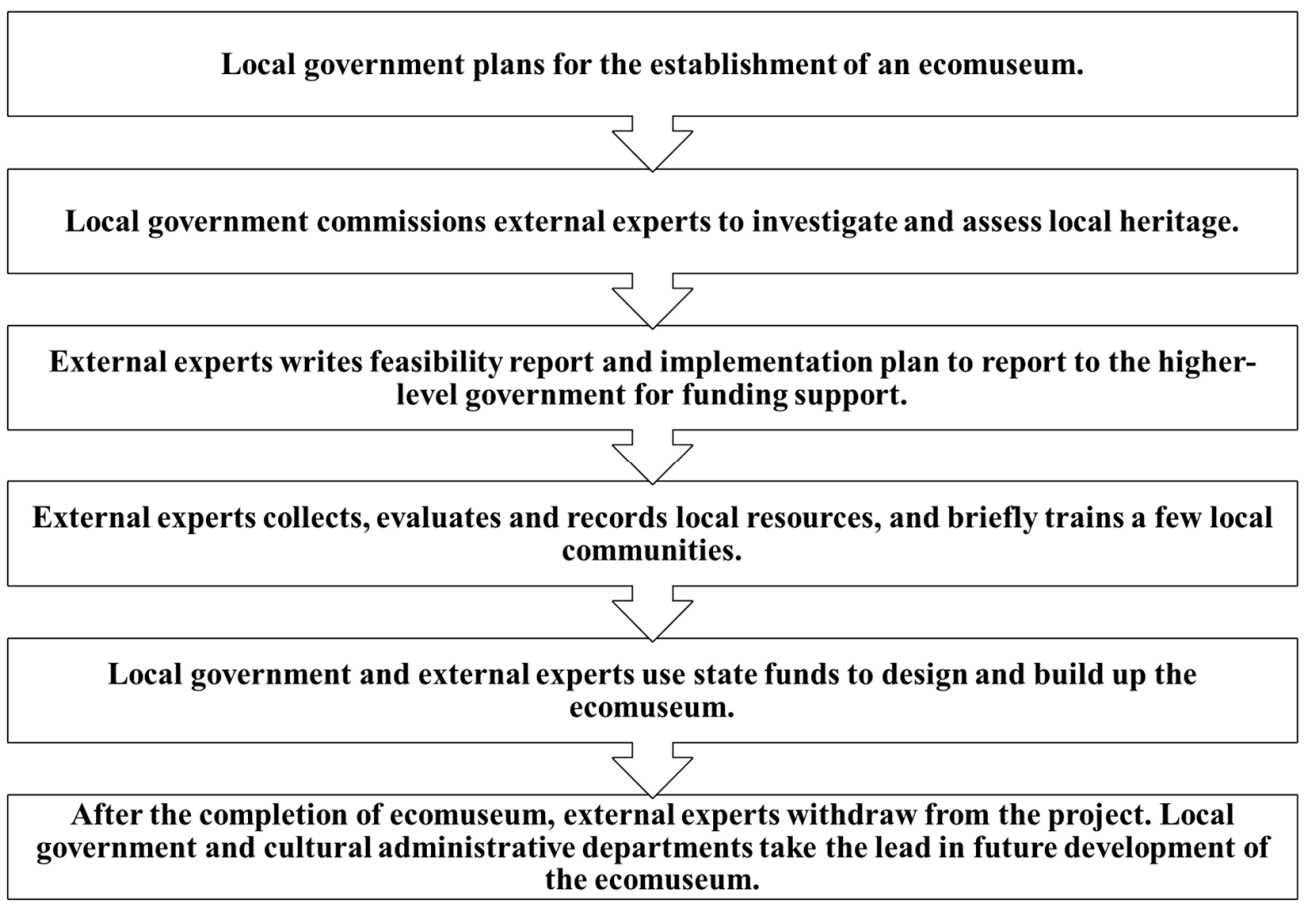

Figure 1. The workflow / framework for existing ecomuseum practice in China.

To practice ecomuseums in China, the first thing is to instil the idea of ecomuseums in officials; if officials do not practice ecomuseums, no one could. In China, if the government does not approve setting up a cultural institution in one place, it cannot be set up, which is different from the West [26] (p. 111).

Therefore, building an ecomuseum in China is not difficult, but maintaining it is, because building it is the act of local government and outside experts, while sustainable development requires the lasting contribution of the local community [56]. Hence, for instance, the operation of ecomuseums faced serious financial difficulties whether under the supervision of the government or local villagers [71]. This is because if the local governments are leaders of the project, they need to be responsible for the project to its end, including continued funding support. From the beginning, it was difficult for communities to recognise the ecomuseum as part of their lives; therefore, it is difficult for the ecomuseum to survive if the local government cannot support it on a sustained basis. Hence, despite 
the complete structure and layout, there is still the problem of creating a sense of place in the practice of Chinese ecomuseums [44,72,73].

This means that the ecomuseum in China is a rapidly established institution rather than a long-term process of community self-discovery, nurturing, understanding, development and management. The existing practical framework has clear short-term goals but lacks long-term aims to stimulate community's participation. Such short-sighted framework can be reflected via the development of China's ecomuseum of different generations. For the first two generations of China's ecomuseums, poverty alleviation and cultural diversity conservation have become the two targets. Massive infrastructure construction was a part of the project, because the first two generations were aimed to express the "Chinese style" of rich and diverse cultures, especially to include ethnic groups that are mostly rooted in remote and underdeveloped areas [74] (p. 28-29). The third generation, i.e., Anji Ecomuseum, took improvement of local economic interests as an important consideration through collecting all local cultural resources and branding them [42]. Nevertheless, the proportion of the industrial ecomuseum was too large; therefore, the development of the Anji ecomuseum was abnormal [44] (p. 113). In addition, Pan, the founder of Anji, mentioned in a phone conversation in October 2020 that the current focus of the Anji Ecomuseum is no longer protecting local culture but developing the regional economy. The most direct way to develop regional economies with ecomuseums is to develop tourism. Therefore, many scholars have discussed the relationship between ecomuseums and tourism, e.g., [75-80]; most of these discussions are based on measurement of the mutual influence of tourism and ecomuseum, and they often end up forging a difficult balance between heritage protection and tourism development.

This is because, in the absence of long-term community development aims, and strongly stimulated by short-term goals, the community has not yet had time to thoroughly understand and participate in the idea of an ecomuseum, while only being eager to obtain immediate benefits. For instance, large numbers of exquisite and precious artefacts that were found during the initial establishment of the first-generation ecomuseums in Guizhou were not properly preserved but sold by villagers to the foreign tourists brought by the opening of the village to tourism [81]. Similar situations arise in other underdeveloped locations, e.g., the second generation of ecomuseums in Guangxi [82], which have presented great difficulties for the preservation of heritage and cultural relics [70]. However, things become a little better when the practice moves out of remote and poor rural areas into affluent and better-educated urban areas. In 2012, Sanfang Qixiang Community Museum was established in Fuzhou, Fujian Province. This is the first community museum in China which was established as a part of the third-generation ecomuseum (community museum) project [83]. The community museum consists of one central exhibition hall, 37 themed exhibition halls and 24 exhibition points [84,85], based on the model of 'territory + traditions

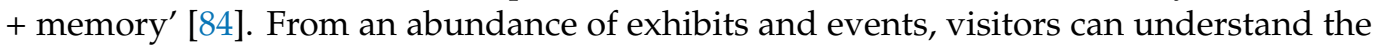
local history, traditions and stories [83]. Moreover, communities are encouraged by the project to be involved in the construction of the community museum [85]; therefore, during the collection and interpretation of old stories, the traditions and memory of local residents are not only promoted to visitors but also strengthened among members of the community.

The pursuit of short-term goals at the expense of long-term plans is worse in locations of greater poverty. As mentioned, the ability of the community participation is related to the level of economic development of the community. Fang [52] interviewed the residents of Longga Village (part of the first-generation ecomuseums) after the ecomuseum was built, many of whom said that economic interests were the most important to them and that they hoped their future generations would receive better education and be admitted to universities instead of living the life of their forefathers. The villagers were also eager to live like city dwellers, but the practice of ecomuseums protected the original buildings and did not allow them to demolish the grass houses, and this went against the villagers' wishes. There are also many villagers who are desperate to escape from poverty and go out to work but find themselves frustrated by their lack of education. In short, a group has 
to solve the problems of survival before talking about cultural autonomy [86,87]. As well as this, in the case of extreme economic underdevelopment, the group would feel its own culture was inferior, thus speeding up separation from its original culture and catching up with the more advanced culture [35].

Driven by goals of short-term economic benefits, the practical framework of ecomuseums in China is still "heritage-oriented", which emphasises the cultural value of local heritage and its potential to be transformed into economic value, rather than "(community) people-oriented". External experts and the local government often quickly assess, gather and display the local heritage to form a point that can be used to develop tourism. For the community, this is a rapid process, and they participate more like "interviewees" assisting in collecting local heritage and building ecomuseum rather than being "self-discoverers". For instance, the construction of the first-generation ecomuseums engages villagers in assisting in building information centres [2] and encourages young people in the village to assist in documenting their culture by using their own language [88]. However, these superficial initial participations have not been reinforced by long-term goals and are gradually abandoned afterwards when the external experts completed and withdrew from the projects. The memory project is obviously missing; many changes over the 10 years, since the ecomuseum was built in 1998, were not recorded, and the local culture is disappearing very quickly [81]. There are frequent personnel changes in the ecomuseum, and their working approach is unprofessional and disorganised, in addition to the lack of local community participation; although some update has been implemented since the ecomuseum was completed, it has been very hasty and careless [52].

Communities certainly have opinions about their own cultural values, but they cannot grasp the purpose and significance of an ecomuseum as a long-term, community-oriented development plan within the existing practical framework. However, people can find through the short-term, heritage-oriented practical framework that local heritage has economic value; hence, they tend to follow the visible short-term benefits to utilise their heritage, which often turns out to be simple and crude. For instance, the original traditional activity to celebrate men and women falling in love, called 'Tiaohua', has developed into the 'Tiaohua Festival' in order to meet the needs of tourism development, which needs to be performed in a designated venue. The ecomuseum used to ask villagers to perform and give them small gifts, but now, the villagers require the ecomuseum to pay for the performance [81]. This is typical of the forcible 'materialisation' of intangible memory and culture; the logic behind this is simple and crude: the performance can make money after being fixed; therefore, it does not matter if it loses its original life and value, which leads the ecomuseum to become 'mercenary' and to fall into a vicious circle. The practice of the second-generation in Guangxi faces the dilemma of a shortage of operating funds and imperfect legal provision after the completion of the project [89]. These difficulties directly lead local governments to increase the development of tourism, thus ignoring the purpose of ecomuseums to protect cultural heritage [70]. Authors should discuss the results and how they can be interpreted from the perspective of previous studies and of the working hypotheses. The findings and their implications should be discussed in the broadest context possible. Future research directions may also be highlighted.

\section{Ways Forward for Longer Term Sustainable Ecomuseums}

The current practical framework of ecomuseums in China needs to be changed into the setting of long-term goals and consequently the roles played by all parties, to enhance sustainable community participation. Therefore, a "growth framework" (Figure 2) is proposed to replace the existing "falloff framework", which has a key step of in-depth consultation. Compared with the existing framework, one outstanding advantage of the proposed framework is that it is conducive to the self-nurturing of the community and local government and the establishment of long-term goals of the ecomuseum (Table 1). The driver of long-term goals should be (community) people-oriented; therefore, willingness of community is the most crucial. In a case study of a small sample, J. Han et al. [90] also 
proposed that the ecomuseum can be used as a long-term working tool for preserving living heritage, and that a heightened sense of community is an important prerequisite for its success. In addition, as mentioned in the beginning of this article, willingness to preserve their own culture of the community was an important foundation for the success of Ak-Chin ecomuseum, but as analysed, community participation in China lacks the bottom-up ability to negotiate; therefore, intermediaries are needed to coordinate and reflect community' willingness. External experts should act as intermediaries, and the coordination process must be given enough time and treated with great patience for community consultation. Community counselling is not just fieldwork, as the example of Southwell [21] which is still ongoing. In this project, researchers did not directly ask the community to understand the idea of ecomuseum or immediately inform them with the construction and plan. Instead, they carried out many activities such as community events, focus group interviews, and community family activities to understand the community's desires and difficulties for development. These consultations focused not only on the heritage of the community, but also their daily life, feelings, and the local agricultural specialties, etc., which established great foundation for the community's participation in the ecomuseum project. It is clear that community certainly deserves external assistance, including expertise, advice, and a wide range of resources, but this must be based on community's willingness and not just on the "professional" judgment made by external experts. In addition, external experts must remain neutral to mediate potential conflicts between local government and community; therefore, it is also important to understand the position and needs of local government. External experts can only give due advice on the basis of community consultation and local government consultation, which includes both short-term and long-term expectations from both sides.

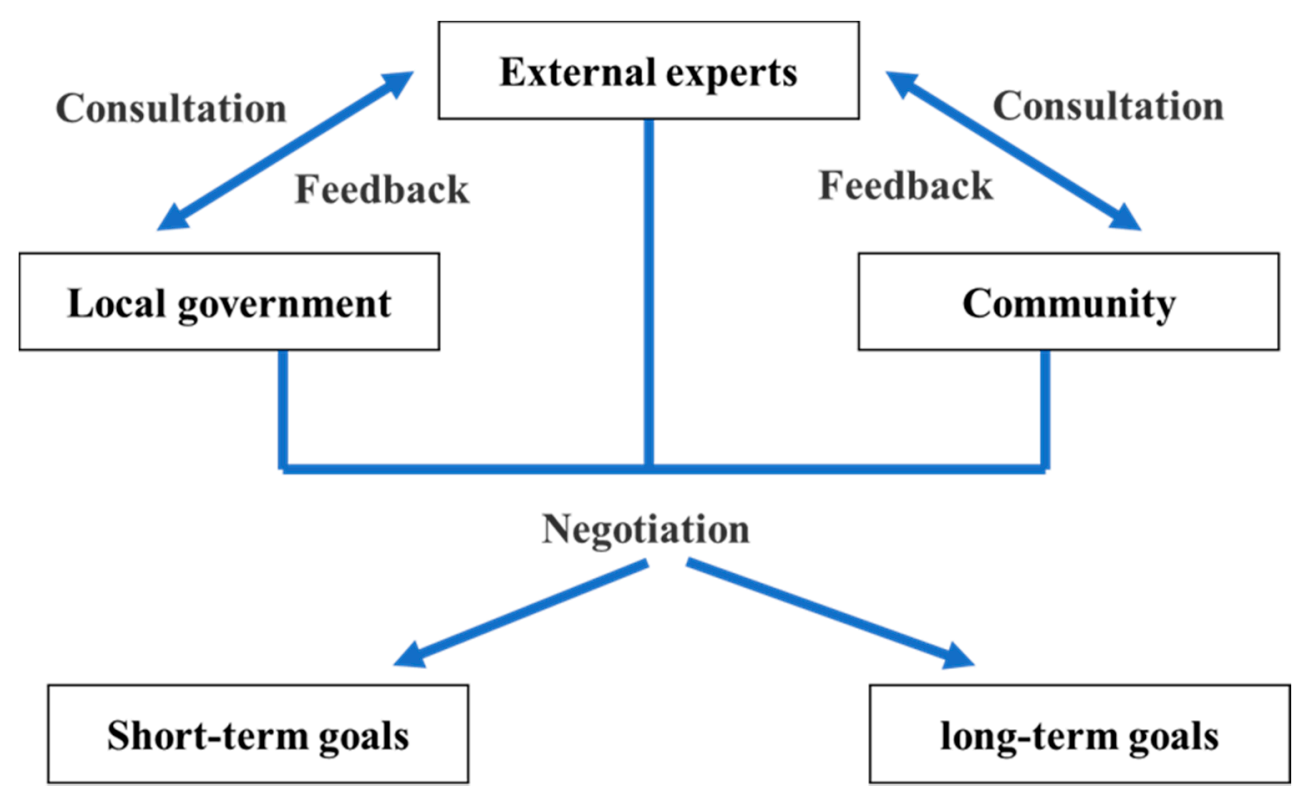

Figure 2. A brief proposed workflow/framework for ecomuseum practice in China.

Replacing the current purely fieldwork process with a full consultation session helps community and local government set the long-term goals for the ecomuseum and also helps the existing three parties to adjust their roles. In the case of Ak-Chin [19], it can be seen that at first, two community residents participated in the local archaeological excavation after training, and then they volunteered to start community consultation. After this, the community council began to seek for external resources and assistant, and finally a board of directors was formed and formulated a long-term community selftraining plan. This process shows that the community is potentially capable of setting reasonable long-term development goals, where the role of community council here could be played by local government. The administrative power of local governments should 
be used more rationally, such as requesting village leaders to organise various activities and provide comfortable environment for villagers to participate or encouraging the community to set up various groups in accordance with their roles. The approach of intergroup cooperation for local communities of the Miura Peninsula Ecomuseum is a good example to demonstrate well-organised and sorted community activities. Under this approach, three self-organised local community groups, including "history-oriented", "environment-oriented" and "culture-oriented", have been working in parallel but also interdisciplinary on the relevant aspects of the ecomuseum project, and eventually, they achieved lifelong learning of local communities together [91] (p.187-189).

Table 1. A comparison of existing and proposed frameworks.

\begin{tabular}{|c|c|}
\hline The Existing Framework: Falloff Mode & The New Framework: Growth Pattern \\
\hline \multicolumn{2}{|c|}{ Advantage } \\
\hline $\begin{array}{l}\text { - } \quad \text { Money can be raised quickly. } \\
\text { - } \quad \text { The construction of ecomuseum can be quickly. } \\
\text { - The short-term achievements of local government is clear. }\end{array}$ & $\begin{array}{l}\text { - Local community can be deeply involved. } \\
\text { - } \quad \text { Long-term self- nurturing for local governments and } \\
\text { communities. } \\
\text { - The ecomuseum can be truly rooted in the long-term } \\
\text { development of the area. } \\
\text { - Ecomuseum can establish long-term cooperation } \\
\text { mechanisms with external experts. }\end{array}$ \\
\hline
\end{tabular}

\section{Disadvantage}

- Deep community participation is difficult to be achieved.

- It is difficult for ecomuseum to achieve sustainability.

- $\quad$ There is no long-term cooperation mechanism between external experts and ecomuseum.
- It may be difficult to raise funds for the construction of ecomuseum, especially in the early stage.

- The construction speed of ecomuseum may be slow.

In addition, external experts should not refer their job only as a brief fieldwork in the area, quickly wrap up after construction of an ecomuseum and leave. They should be relieved of their authority and act as patient and impartial intermediaries for long-term partnership with local governments and communities. This also requires local government's attention, such as establish a cooperative mechanism and a wide range of long-term cooperation with the outside, not just with a particular university or research institute, but with a wider range of interdisciplinary and industry professionals.

The construction of ecomuseums in China at this stage is almost impossible to be divorced from the short-term goal of improving regional economic development, but this does not cause the community and local government to form a long-term development consensus after receiving in-depth consultation. What may be lacking most is patience.

\section{Conclusions}

In conclusion, after nearly 30 years of practice, ecomuseums in China have formed a unique practical framework. The practice always is a result of a top-down decision which stems from the will of a small group of the elite or ruling class and is often in line with macropolicies for local and even national development. After the practice of the second generation, scholars of both theory and practice realised that the first challenge of ecomuseum practice in China is that it cannot solve the huge contradiction between villagers' desire to expand economically and ecomuseums' aim of protecting cultural heritage in remote areas. This is more like a substantial gap between Western theory and Chinese practice. The third generation is intended to reassess the feasibility of ecomuseums in China. It is hoped that in economically developed areas of China, ecomuseums would be as vibrant as in Western countries, where balance can be found in the relationship between economic development and heritage conservation. Even so, under the top-down national framework, the third generation has failed to fulfil its mission of protecting local cultural integrity and achieving deep community participation. 
It must be recognised that adopting the practice of the ecomuseum is not simply a reference to its organisational structure and layout model but more importantly to absorbing its core concept, which is that the ecomuseum is a people-oriented process of slowly growing community development. On the premise that the top-down macro framework of the country cannot be changed, the existing practical framework of the ecomuseum must be revised. In other words, the existing 'decline type' practice framework should be revised into a 'growing type' framework. A long and patient consultation process with the involvement of external experts is key to assist local governments and communities to establish long-term community and ecomuseum development goals. In short, the purpose of the adjustment of the framework is to reverse the current model of 'quick success and instant benefits' and to turn the whole framework into a long-term development model of 'difficult before easy'. In this transformation process, the culture, memory and daily life of communities is constantly strengthened and displayed. Through a patient consultation process, local government and communities need to enhance self-nurturing so as to truly become the owners of ecomuseums. This is also in line with Yin's [44] recommendations for future ecomuseum practices in China: in order to consciously avoid being domesticated by mainstream ideologies, emphasis on the identification of local culture and the display of daily life should be key.

Author Contributions: Conceptualization, M.L. and G.S.; methodology, M.L. and G.S.; formal analysis, M.L. and G.S.; investigation, M.L.; resources, M.L. and G.S.; data curation, M.L.; writingoriginal draft preparation, M.L.; writing-review and editing, M.L. and G.S.; supervision, G.S.; All authors have read and agreed to the published version of the manuscript.

Funding: This research received no external funding.

Data Availability Statement: Not appliable.

Conflicts of Interest: The authors declare no conflict of interest.

\section{References}

1. Bilas, V.; Trifunić, L. Ecomuseum-a contemporary concept and key solution for valorisation of heritage and sustaniable development in the European Union. In Proceedings of the FEB Zagreb 12th International Odyssey Conference on Economics and Business, Szybenik, Chorwacja, 9-12 June 2021; Braje, I.N., Jaković, B., Hodak, D.F., Eds.; Faculty of Economics \& Business University of Zagreb: Šibenik, Croatia, 2021; pp. 161-172.

2. Davis, P. Ecomuseum: A Sense of Place; Continuum: New York, NY, USA, 2011.

3. Salvatore, C.; Luigi, G.C.; Teresa, G. Limits and Potentialities of Ecomuseums in Sicily, between Tourist Exploitation and Cultural Heritage Preservation. In Proceedings of the 5th International Congress on "Science and Technology for the Safeguard of Cultural Heritage in the Mediterranean Basin", Istanbul, Turkey, 22-25 November 2011; Centro Copie I'Istantanea: Istanbul, Turkey, 2011; pp. 442-450.

4. Farsani, N.T.; Taheri, S.; Tazeh, M.; Malekzadeh, F. Desert Ecomuseum Positioning: Yazd Province, (IRAN). Acta Geoturistica 2014, $5,37-44$.

5. Corsane, G. Using ecomuseum indicators to evaluate the Robben Island Museum and World Heritage Site. Landsc. Res. 2006, 31, 399-418. [CrossRef]

6. Corsane, G.E.; Davis, P.S.; Hawke, S.K.; Stefano, M.L. Ecomuseology: A holistic and integrated model for safeguarding 'spirit of place' in the North East of England. In Proceedings of the 16th ICOMOS General Assembly and International Symposium: 'Finding the Spirit of Place-Between the Tangible and the Intangible', Quebec City, QC, Canada, 29 September-4 October 2008.

7. Davis, P. Ecomuseums and Sustainability in Italy, Japan and China: Concept Adaptation through Implementation. In Museum Revolutions: How Museums Change and are Changed; Knell, S.J., MacLeod, S., Watson, S.E.R., Eds.; Routledge: Oxfordshire, England, UK, 2007; pp. 198-214.

8. Holbrow, D. Museums and Culture. Prairie. Forum. 2019, 40, 39-45.

9. Akkar Ercan, M.; Bingül Bulut, M.B.; Bugeja, B.; Kaya, Y.; Magaz Molina, J.; Shurdi, S. InTransientKaraya: Approaches for Developing Knowledge, Meaning, and community identity in abandoned UBH. In Underground Built Heritage Valorisation: A Handbook, Proceedings of the First Underground4value Training School, Castel dell'Ovo, Naples, Italy, 10-15 February 2020; Pace, G., Salvarani, R., Eds.; COST Association: Brussels, Belgium, 2021; pp. 363-372.

10. MacPherson, A.L. Case Study:Calling Lakes Ecomuseum (CLEM). Prairie Forum 2019, 40, 56-58.

11. Massey, S. Living Heritage and the Ecomuseum. Prairie Forum 2019, 40, 30-38. 
12. Barros, F.P.; Santos, D.M.; de Andrade, N.A.; de Lira Freitas, A.; Neto, A.C.; Bezerra, D.H.S.; de Holanda Leite, M.J.; de Araújo Brilhante, J.C. The natural ecomuseum of mangrove: Educational and reforestation actions. Braz. Appl. Sci. Rev. 2021, 5, $482-497$. [CrossRef]

13. Rivard, R. Ecomuseums Today-Tools for Sustaninability? Pac. J. 2019, 40, 15-28.

14. Ghorbanzadeh, M. Rural Tourism Entrepreneurship Survey with Emphasis on Eco-museum Concept. Civ. Eng. J. 2018, 4, 1403. [CrossRef]

15. Layne, V. The District Six Museum:An Ordinary People's Place. Public Hist. 2008, 30, 53-62. [CrossRef]

16. Corsane, G. From "outreach" to "inreach": How ecomuseum principles encourage community participation in museum processes. In Proceedings of the Communication and Exploration: Papers of the International Ecomuseum Forum, Guizhou, China, 1-4 June 2005; Su, D., Ed.; Forbidden City Press: Beijing, China, 2006; pp. 155-171.

17. Sutter, G.C.; Sperlich, T.; Worts, D.; Rivard, R.; Teather, L. Fostering Cultures of Sustainability Through Community-Engaged Museums: The History and Re-Emergence of Ecomuseums in Canada and the USA. Sustainability 2016, 8, 1310. [CrossRef]

18. Doğan, M.; Timothy, D.J. Beyond Tourism and Taxes: The Ecomuseum and Scocial Development in the Ak-Chin Tribal Community. J. Tour. Cult. Chang. 2020, 18, 133-149. [CrossRef]

19. Fuller, J.N.; Luo, X.; Zhang, S. Concept and Approach of Ecomuseum:Introduction to the AK-Chin Indian Community Ecomuseum Project (生态博物馆的概念与方法一介绍亚克钦印第安社区生态博物馆计划). Chin. Mus. 1993, 04, 73-82.

20. Cassidy, L. Recalling Community:Using material culture and digital archives in Salford. Int. J. Community Res. Engagem. 2012, 5, 166-182.

21. Massing, K. Learning to Let Go: The Process of Establishing an Ecomuseum in Southwell. Mus. Int. 2019, 71, 144-155. [CrossRef]

22. Johnston, M.P. Secondary Data Analysis: A Method of which the Time Has Come. Qual. Quant. Methods Libr. $2014,3,619-626$.

23. Doolan, D.M.; Froelicher, E.S. Using an existing data set to answer new research questions: A methodological review. Res. Theory Nurs. Pract. 2009, 23, 203-215. [CrossRef] [PubMed]

24. Dale, A.; Arbor, S.; Procter, M. Doing Secondary Analysis; Unwin Hyman: London, UK, 1988.

25. Nitzky, W. Entanglements of "Living Heritage": Ecomuseum Development in Rural China. Ph.D. Thesis, Arizona State University, Tempe, AZ, USA, 2014.

26. Nitzky, W. Reflections and Visions of Chinese Ecomuseum一An Interview with Mr. Donghai Su (中国生态博物馆的反思与瞻 望一苏东海先生访谈). Chin. Mus. 2011, 109-115.

27. Nitzky, W. Ecomuseums with Chinese Characteristics: The Politics of Safeguarding Living Heritage. In Proceedings of the Ecomuseums 2012: Proceedings of the 1st International Conference on Ecomuseums, Community Museums and Living Communities, Seixal, Portugal, 19-21 September 2012; Lira, S., Amoêda, R., Pinheiro, C., Davis, P., Stefano, M., Corsane, G., Eds.; Green Lines Institute: Barcelos, Portugal, 2012; pp. 245-255.

28. Nitzky, W. Mediating Heritage Preservation and Rural Development: Ecomuseum in China. Urban Anthropol. 2012, 41, 367-417.

29. Massing, K. Safeguarding intangible cultural heritage in an ethnic theme park setting-the case of Binglanggu in Hainan Province, China. Int. J. Herit. Stud. 2018, 24, 66-82. [CrossRef]

30. Massing, K. Finding an Ecomuseum Ideal for Hainan Province: Encouraging Community Participation in Intangible Cultural and Natural Heritage Protection in a Rural Setting in China. Ph.D. Thesis, Newcastle University, Newcastle upon Tyne, Tyne and Wear, UK, 2016.

31. Borrelli, N.; Ge, R. An Analysis of Chinese Ecomuseums in Relation to Ecomuseum Theories and Principles. Organon 2019, 51, 123-151. [CrossRef]

32. Stewart, D.W.; Kamins, M.A. Secondary Research: Information Sources and Methods; Sage: Newbury Park, CA, USA, 1993.

33. Fang, L. Who Has the Power of Cultural Interpretation? (谁拥有文化解释的权力?). Art Rev. 2005, 8, 4-9. [CrossRef]

34. Fang, L. Beware of Potential Cultural Colonization Trends: Challenges to the Concept of Ecomuseums (警惕潜在的文化殖民趋 势——生态博物馆理念所面临的挑战). Minzu Arts 2005, 3, 6-12. [CrossRef]

35. Fang, L. The Deep Social Background of Intangible Cultural Heritage Protection: Research and Reflection on The Suojia Ecomuseums in Guizhou (非物质文化遗产保护的深层社会背景——贵州梭嘎生态博物馆的研究与思考). Natl. Arts Bimon. 2007, 4, 6-20. [CrossRef]

36. Pan, S. Ecomuseums in China (生态博物馆在中国). Chin. Cult. Herit. 2011, 6, 66-70.

37. Pan, S. Ecomuseums and Their Development in China: Historical Observations and Reflections (生态博物馆及其在中国的发展: 历史性观察与思考). Chin. Mus. 2011, 24-33.

38. Pan, S. Contemporary Intangible Cultural Heritage Protection and Eco-museum Constructions Predicament (当代非物质文化遗 产保护传承与生态博物馆建设困境). J. Gannan Norm. Univ. 2013, 20-25. [CrossRef]

39. Pan, S. Theoretical Discussion on the Third-Generation Ecomuseum and the Construction of Anji Ecomuseum Cluster (“第三 代”生态博物馆与安吉生态博物馆群建设的理论思考). Southeast Cult. 2013, 6, 86-93.

40. Pan, S. A Scan of Current Status of Ecomusuems in China (中国生态博物馆现况扫描). China Cult. Dly. 2015, 008.

41. Pan, S. Self-cognition and Self-education at Ecomusem: From "Information Center" to "Cognition Center". Sci. Educ. Mus. 2015, 1,35-37.

42. Pan, S. The Ecomuseum (Community Museum): Chinese Experiences and Critical Discussions (生态/社区博物馆的中国经验与学 术性 批判反思). Southeast Cult. 2017, 6, 115-128. 
43. Pan, S. Consider the contemporary dimensions of ecomuseums- Prologue for “Ecomuseum: Tought, Theory and Practice" (思考 生态博物馆的当代维度—《生态博物馆:思想、理论与实践》序). In Ecomuseum: Tought, Theory and Practice; Science Press: Beijing, China, 2019.

44. Yin, K. Ecomuseum: Thought, Theory and Practice (生态博物馆: 思想、理论与实践); Science Press: Beijing, China, 2019.

45. Glaser, B.G. Retreading Research Materials: The Use of Secondary Analysis by the Independent Researcher. Am. Behav. Sci. 1963, 6, 11-14. [CrossRef]

46. Braun, V.; Clarke, V. Using thematic analysis in psychology. Qual. Res. Psychol. 2006, 3, 77-101. [CrossRef]

47. Braun, V.; Clarke, V. One size fits all? What counts as quality practice in (reflexive) thematic analysis? Qual. Res. Psychol. 2020, 18, 1-25. [CrossRef]

48. Su, D. The Concept of the Ecomuseum and its Practice in China. Museum Int. 2008, 60, 29-39. [CrossRef]

49. Zhao, M.; Cheng, Z.; Ni, A.; Xu, H. Digital Protection of Intangible Cultural Heritage and the Construction of Eco-museum: A Case Ctudy of the Protectionn of Five Gong Mode in Haizhou (非物质文化遗产数字化保护与生态博物馆建设一一海州五大宫 调保护为例). J. Huaihai Inst. Technol. 2014, 12, 71-75. [CrossRef]

50. Su, D. Chinese Ecomuseum:The Path of Development(中国生态博物馆的道路). In Proceedings of the Communication and Exploration: Papers of the International Ecomuseum Forum, Guizhou, China, 1-4 June 2005; Su, D., Ed.; Forbidden City Press: Beijing, China, 2006; pp. 5-10.

51. Gan, D. The Paradox of Eco-museum Chinalisation (生态博物馆中国化的悖论). J. Minzu Univ. China 2009, 36, 68-73.

52. Fang, L. Life Changes in Longga Village: Research on The Suojia Ecomusuem (陇戛寨人的生活变迁一梭戛生态博物馆研究); Xueyuan Press: Beijing, China, 2010.

53. Sun, j.; Ma, T. “Community Participation: Analysing the Fate of Jinuo Ethnic Ecological Museum (巴卡小寨民族生态博物馆的命 运解读:社区参与的视角)". J. Orig. Ecol. Natl. Cult. 2010, 2, 90-95.

54. Tong, X. “On the Model of Community Participation in Tourism Development of Eco-Museum (生态博物馆的社区参与模式初 探)". J. Guilin Inst. Tour. 2007, 18, 666-669.

55. Stojevic, I. Village and Heritage in China: A Discussion on the Influence and Future of HeritageWork in Rural Areas. Heritage 2019, 2, 43. [CrossRef]

56. Su, D. The establishment and sustainable development of ecomuseums in China (建立与巩固: 中国生态博物馆发展的思考). In Proceedings of the Communication and Exploration: Papers of the International Ecomuseum Forum, Guizhou, China, 1-4 June 2005; Su, D., Ed.; Forbidden City press: Beijing, China, 2006; pp. 1-4.

57. Gusfield, J.R. The Community: A Critical Response; Harper Colophon: New York, NY, USA, 1975.

58. McMillan, D.W.; Chavis, D.M. Sense of community: A definition and theory. J. Community Psychol. 1986, 14, 6-23. [CrossRef]

59. Ding, Y. Community building in China: Issues and directions. Soc. Sci. China 2008, 29, 152-159. [CrossRef]

60. Fan, L. International influence and local response: Understanding community involvement in urban heritage conservation in China. Int. J. Herit. Stud. 2014, 20, 651-662. [CrossRef]

61. Zhang, F. The development process and modern trend of rural community governance since the foundation of the new China (新 中国成立以来农村社区治理的 发展进程与现代走向). Rural Econ. Sci. Technol. 2019, 30, 255-257.

62. Den, W. Community Empowerment and Heritage Conservation: The Experience of Beitou District in Taipei City, Taiwan. Hist. Environ. Policy Pract. 2014, 5, 258-274. [CrossRef]

63. Li, J.; Krishnamurthy, S.; Roders, A.P.; van Wesemael, P. State-of-the-practice: Assessing community participation within Chinese cultural World Heritage properties. Habitat Int. 2020, 96, 1-11. [CrossRef]

64. Lu, J. Policy consideration on cultural heritage protection and management in China (中国文化遗产保护管理的政策思考). Southeast Cult. 2010, 216, 22-29.

65. Head, B.W. Community engagement: Participation on whose terms? Aust. J. Polit. Sci. 2007, 42, 441-454. [CrossRef]

66. Safford, L.B. Cultural Heritage Preservation in Modern China: Problems, Perspectives, and Potentials. ASIANetwork Exch. 2014, 21, 3-15. [CrossRef]

67. Tong, Y.; Ma, H. Community Participation一The Key to Protection for Rural Cultural Heritage (社区参与-促进农村文化遗产保护 之关键). Rural Econ. 2009, 25, 109-112.

68. Yang, F. Ethnic heritage in Yunnan: Contradictions and challenges. In Reconsidering Cultural Heritage in East Asia; Matsuda, A., Mengoni, L.E., Eds.; Ubiquity Press: London, UK, 2016; pp. 87-102.

69. Yin, K. Utopian Imagination: The Idea of Multicultural and Ecomuseum (乌托邦的想象:多元文化与生态博物馆思想). Chin. Mus. 2016, 4, 5-11.

70. Mo, Z. Exploration Road of Guangxi National Ecomuseum “1 $1+10$ ” Project (广西民族生态博物馆1+10工程探索之路). Chin. Cult. Herit. 2015, 1, 32-39.

71. Yi, S.H. Examining the Suojia Ecomuseum and the Nandan Ecomuseum in China. In Proceedings of the Asian Conference on Arts and Cultures; Srinakharinwirot University: Bangkok, Thailand, 2013; pp. 168-177.

72. Yin, K. “Multi-senses of Place: An Approach to Ecomuseum (地方的多重感知:一种生态博物馆的路径)”. Folk. Stud. 2017, 158, 21-28. [CrossRef]

73. Yin, K. “Museum Architecture in Villages: Reflections on the Practice of Chinese Ecomuseum (村落中的博物馆建筑:中国生态博 物馆的实践反思)". Chin. Mus. 2017, 2, 48-54. 
74. Rong, X. Ecomuseums in Guangxi: Establishment, Exploration and Expectations (广西生态博物馆建设探索与规划). In Proceedings of the Communication and Exploration: Papers of the International Ecomuseum Forum, Guizhou, China, 1-4 June 2005; Su, D., Ed.; Forbidden City Press: Beijing, China, 2006; pp. 28-32.

75. Zhang, T. Ecomuseum, Tourism and Local Development (生态博物馆、旅游与地方发展). J. Southwest Minzu Univ. 2011, 32, 115-120. [CrossRef]

76. Ru, J. The Way to Achieve Double Responsibility一Brief Analysis of Ecomuseum and Development of Tourism (实现双重责任的 途径-浅析生态博物馆与发展旅游). Chin. Mus. 2001, 5, 19-26.

77. Zhou, J. Eco-tourism: Equilibrium Points between Ecological Protection and Tourism Development of Eco-museum (生态旅游:生 态博物馆生态保护 与旅游发展的平衡点). J. Guangxi Univ. Natl. 2008, 30, 41-44.

78. Chen, Y. Eco-museum: The Harmonious Integeration of Tourism Development and Cultural Protection: An Idea of Eco-museum of the Hani's Terraced-Field Culture in Yuanyang (生态博物馆: 旅游开发与文化保护的和谐统一建立云南元阳哈尼族梯田文化生 态博物馆的构想). J. Honghe Univ. 2009, 7, 6-10.

79. Yu, Q.; Wu, B. Eco-Museum: A Model for Sustainable Tourism Development of Ethnical Culture (生态博物馆:一种民族文化持续 旅游发展模式). Hum. Geogr. 2001, 16, 40-43.

80. Jin, L. The ecomuseum as an imaginary destination in China: The transition of the concept "ecomuseum" from France to China. In Proceedings of the 1ères DOCTORIALES du Tourisme de la Chaire "Culture, Tourisme, Développement »: TOURISME Concepts and Methods at the Disciplinary Crossroads, Fondation Hellénique, Cité Internationale Universitaire de Paris, Paris, France, 14-16 September 2011; pp. 1-17.

81. Meng, F.; Su, D.; Fang, L.; An, L. Construction of Ecology Museum and Development of Ethnic Culture: A Case Study of Suoga Ecology Museum (生态博物馆建设与民族文化发展一一梭戛生态博物馆为中心的讨论). J. Orig. Ecol. Natl. Cult. 2017，9， $128-140$.

82. Nong, X. Practice and Exploration of Guangxi National Ecomuseums (广西民族生态博物馆的实践与探索). In Proceedings of the China Minzu Culture and Museum; Professional Committee of Minzu Museums of China Museum Association: Beijing, China, 2010; pp. 80-93.

83. Hu, B.; Huang, Y. Comparison of Two Community Museums in China and U.S: A Case Study of Anacostia Community Museum in Washington D.C. and Sanfang Qixiang Community Museum in Fuzhou (中美两座社区博物馆的对比与启示-以华盛顿安那考 斯提亚社区博物馆与福州三坊七巷社区博物馆为案例的解读). Mus. Stud. 2017, 3, 3-9. [CrossRef]

84. Wang, Q.; Huang, J.; Li, X. Study of Chinese Community Museum Development and Management: A Case Study of Sanfang Qixiang Community Museum in Fuzhou (中国社区博物馆发展管理问题研究-以福州“三坊七巷社区博物馆”为例). Manag. Oberservation 2014, 532, 138-139.

85. Lin, J. People-oriented and Living-protection: Exprloration of Sanfang Qixiang Community Museum (以人为本, 活态保护-三坊七 巷社区博物馆的探索之路). Chin. Cult. Herit. 2011, 5, 72-81+7.

86. Fang, L. Pay Attention to the Owners of Intangible Cultural Heritage (请关注非物质文化遗产的拥有者). Art Rev. 2006, 6, 22-28. [CrossRef]

87. Fang, L. Intangible Cultural Heritage Protection in the Context of Globalisation: Reflections on the Investigation of The Suojia Ecomuseum in Guizhou (全球化背景中的非物质文化遗产保护——贵州梭嘎生态博物馆考察所引发的思考). Minzu Arts 2006, 3, 6-13. [CrossRef]

88. An, L.; Gjestrum, J.A. The Ecomuseum in Theory and Practice: The First Chinese Ecomuseum Established. Nord. Museol. 1999, 2, 65-86.

89. Gong, S. Exploration and Practice: Review, Evaluation and Thinking of the $1+10$ Project of Guangxi Ethnic Eco-Museums (探索 与实践:对广西民族生态博物馆“1+10工程”的回顾、评价和思考). Study Ethn. Guangxi 2016, 1, 143-149.

90. Han, J.; Gerard, C.; Wang, L.; Cheng, X.; You, Y.; Gao, Y. An Exploration of the 'Eco museum Ideal' for Living Heritage Management under the Context of Rural Revitalization in China. Adv. Soc. Sci. Educ. Humanit. Res. 2018, 266, 27-38. [CrossRef]

91. Ohara, K. The Current Status and Situation of Ecomuseums in Japan. In Proceedings of the Communication and Exploration: Papers of the International Ecomuseum Forum, Guizhou, China, 1-4 June 2005; Su, D., Ed.; Forbidden City Press: Beijing, China, 2006; pp. 179-191. 